\title{
THE NEW POOR LAW AND THE STRUGGLE FOR UNION CHARGEABILITY
}

Thrasymachus: "Listen then. I define justice or right as what is in the interest of the stronger party."

Plato, The Republic, I, St. 338

While much has been heard in recent times of the evils attaching to "the principles of 1834", other important aspects of the New Poor Law have been seriously neglected. The laws of settlement and removal were unjust and inhumane, and the system of parochial rating was anomalous, uneven and, indeed, thoroughly iniquitous. One of the main features of the Poor Law Amendment Act had been the grouping of the parishes of England and Wales into unions of parishes. Those of a medium-sized town usually constituted one union, while in the countryside the typical union tended to comprise all the parishes within a radius of up to about ten miles of a country town, its centre. Under the Act, the administration of the Poor Law was based on the union and not, as heretofore, on the parish; yet the latter remained the financial unit, each parish being chargeable for its own Poor Law expenditure. This uneven arrangement prevented the effective operation of the Act, and, as will be shown, had unhappy consequences. Attempts at reform in these matters were strenuously opposed in Parliament between 1845 and 1865 , and only in the latter year was the Union Chargeability Act passed.

The purpose of the present article is to show that the main opposition to reform came from a section of the landed interest whose object was to maintain the status quo with regard to settlement law and to keep alive the pernicious distinction between open and close parishes. Though in the open parish, that is, one where property was divided between numerous owners, overall control was not possible, the close parish, owned by one or two proprietors, could be closely regulated in the interests of the latter, and newcomers refused a settlement. These landowners were thus able to evade paying their share of local taxation while preserving their privileged position in the countryside. In this latter connection, a motive ascribed to the landowners was their desire to maintain aesthetic and social harmony on their parishes and estates. Ugly, squalid, disorderly and otherwise undesirable elements - human, animal and architectural - could be rele- 
gated to adjacent open parishes. ${ }^{1}$ The article traces the course of this twenty-year struggle and indicates how reform was finally achieved.

The New Poor Law made only trifling changes in the laws of settlement and of removal. A man who left his native village at an early age to take up employment in a distant manufacturing town might work there all his life, marry and bring up a family. Nevertheless, if he became incapacitated through illness or accident and had to apply for relief, the local authority would seek to have him removed to the place where he was born but where he was no longer known, and where it was unlikely that he would find work if he should recover.

The first attempt to reform the system was made by Sir James Graham, Home Secretary in Peel's Government, when, in 1844, he printed a Bill which was introduced into Parliament in an amended form in the following session. Its terms, which had been drafted by Somerset House, sought to simplify settlement and to free various classes from removal. Its most important provision was that a person who had maintained himself in one place for five consecutive years became irremovable. Further clauses proposed substitution of the union for the parish for purposes of settlement and rating; that is, areas of settlement would be reduced from 14,500 parishes and townships to 630 unions. It was further proposed that each parish or township in a union should pay a proportion of the rate equal to the proportion it had paid seven years before the passing of the Bill. ${ }^{2}$

In presenting his Bill, Sir James Graham spoke of the principle on which poor relief was then given. It depended on the settlement of the individual. Immediately a man claimed relief, the question arose as to the locality in which he should receive it. If he happened to be settled in the place where destitution overtook him, the next question was whether he should be relieved or removed. "What must be the effects", asked Graham, "upon the habits, feelings and all the associations of the individual who applied for relief when, in addition to sickness or poverty, these two questions arose - should he be relieved? and should he be permitted relief in the place where he had resided - the residence he had freely chosen - or should he be removed from that place, with which his associations and habits were bound up, to some far distant locality in which all those ties would cease to

1 This aspect is discussed at length in a leading article in The Times of 29 March 1865.

${ }^{2}$ S. and B. Webb, English Poor Law History, Part II: The Last Hundred Years (London, 1929), p. 421. The terms of Graham's Bill are here detailed, but with the extraordinary omission of the settlement and rating clauses. Without them, the Webbs' comment on the rejection of the Bill by the Commons loses much of its point. 
exist?" The problem was a big one and, after weighing various considerations, he concluded that five years should provide irremovability prospectively. Regarding the settlement clauses, Graham explained that the 1834 Poor Law Amendment Act fixed the administration of the fund for the relief of the poor on a union basis and that these clauses were merely an extension of the details. They had the approval, he claimed, of boards of guardians, clerks of unions and the Poor Law Commissioners.

The Commons would have been willing to accept those parts of the Bill which were intended to protect residence and prevent the manifold cruelties of removal. The settlement clauses, however, were a different matter and they received little support. Only the Radicals favoured them, Bright telling the House that it had long been the practice for landed proprietors in almost every part of the country, being very anxious that there should not be residing upon their estates and in their parishes a larger number of labourers than their tenants could easily employ, to resort to all kinds of tricks and manoeuvres in the country parishes to prevail on the labourers to settle in towns. It was a charge which, with extensions and variations, was to be repeated in future debates on this subject. However, though not one which commended itself to a Parliament in which the landed interest predominated, it was not answered on this occasion. Opposition to the measure was based ostensibly on the ground that it would inflict injury on the poor, since the substitution of the union for the parish would have the effect of destroying all the care the latter had hitherto exercised over them. The unions, it was said, would have no inducement to continue that care. J. W. Henley, member for Oxfordshire, who was to become the spokesman of the country gentlemen on this issue, protested against what he saw as the destruction of the parochial system in England. There was every indication that the Bill would not survive beyond the first reading.

A couple of days later The Times mounted a furious attack on Graham and his measure. The monster change, stated The Times, was the substitution of union for parish. By a sophisticated and treacherous philosophy Graham contemplated a revolution in this country, a total upturning and tossing into new forms of the land they trod on - the terra firma of old England. It was "a project so wild, such a reversal of everything established in this country [...]. We are really awestruck at the depravity of the nature which can contemplate for a moment such a wreck of our country. We believe that having thrown us into unions instead of parishes and counties, it is meant to bring us to a fresh pale of taxation." 3 Graham knew that the rejection of his Bill was inevitable as it stood. He therefore announced in

3 The Times, 13 February 1845. 
June that he did not intend to proceed with the proposed changes in the law of settlement, although he would have a second reading of the Bill in order to reform the law relating to removal. Such was his intention, but in the tumultuous latter half of the 1845 session he was unable to carry it out.

The evils of the laws of settlement and removal were of long standing, and it could well be asked why Graham chose to attempt these reforms at the time he did. His first biographer tells us that his motives were altruistic: that though the task was difficult, thankless and even embarrassing, there existed a moral obligation to intercede for the territorial liberation of the working man and his family. His measure was one he had long contemplated. He had devoted much time and labour to it, and had "urged upon the Cabinet the duty of legislating boldly upon the subject, [...] because the thing to be done in itself was right". ${ }^{4}$ His measure also arose out of the terrible distress resulting from the sending back to their home districts, in 1840, 1841 and 1842, of great masses of people who had gone to work in the manufacturing districts. ${ }^{5}$ The two reasons are not incompatible. Motives are seldom unmixed, and the projected reforms would have been a benefit both to the poor and to the landed interest. Above all they may be seen as a response to the large-scale changes in the structure of society exemplified by the growth and increasing importance of manufacturing towns.

The matter was not allowed to rest for long. In December 1845 Peel had undertaken to remove the corn duties; and in January, soon after the opening of the 1846 session, he submitted his proposals to the Commons. To counterbalance the withdrawal of protection he outlined a number of measures which would be more particularly beneficial to the agricultural interest. These included what were virtually the terms of Graham's Bill of the previous session, though without the settlement clauses. The new Poor Removal Bill was introduced when the battle over the repeal of the Corn Laws was dying down. The feeling of the House appeared to be in its favour and by 4th May it had passed its first and second readings without being debated.

Quite unexpectedly, at the committee stage, J. E. Denison, member for Malton, rose to move an Instruction to the committee to make provision for the establishment of union settlements. In stating his reasons for asking the House to give consent to the proposition, he called attention to the appalling situation regarding rural housing, and quoted evidence from the

${ }^{4}$ W. T. McCullagh Torrens, Life and Times of Sir James Graham (London, 1863), II, pp. $350-53$.

${ }_{5}^{5}$ Peel was quite explicit about this, Hansard, Third Series, LXXXIII, c. 267, 27 January 1846. 
report of the commission appointed to enquire into the employment of women and children in the agricultural districts. The report showed that there existed a dire need for new cottages to house a growing population; that the consequences of families living in cottages having only one bedroom were dirt, disorder, vice and depravity; and that the want of proper housing accommodation existed in the large villages rather than in the detached cottages on the farms. He cited a scandalous situation at Castle Acre, an open parish. Neighbouring parishes were owned by one, two or a few proprietors. The latter, "partly to prevent increase in birth settlements and to keep down the rates, partly from an unwillingness to invest money in cottage property, not only allowed no new cottages to be built, but let the old ones fall into ruin. The resident population of these parishes is therefore gradually reduced, as the labourers are forced to quit them and come to reside in Castle Acre." The competition caused by the newcomers raised house rents throughout the parish and they were forced to pay exorbitant rents for very wretched dwellings. Conditions at Castle Acre encouraged the use of the notorious "Gang" system of labour with its accompanying immorality and hardship. Unfortunately, Castle Acre was not untypical, and Denison spoke of similar conditions in the Yorkshire Wolds, where labourers and their families had to resort to the small towns for shelter. Often the farmer wanted labour near at hand and put the labourer in some stable or loft to sleep five nights a week, paying his wages partly in money, partly in food. The labourer was much worse off.

Denison estimated that the proportion of close to open parishes, taking the country through, was nearly equal. He gave the examples tabulated below.

Unions

No of Parishes

Close

Open in Unions

Southwell

Loughborough

Shardlow

Basford

Malton

Norfolk (Tunstead

and Happing Hundred)
60

23

46

43

68

41
28

12

23

21

31

20
32

11

23

$20^{6}$

37

21

The effect was that half the parishes had to support the poor of the other half, who were entirely thrown on them for maintenance. The remedy was

6 doubtful. 
to change from parish to union settlement. The landowner would then have no inducement to pull down cottages - rather the contrary. If the landed proprietor were compelled to support the poor and destitute of the union, whether they resided in his parish or in an adjoining one, his interest would induce him to take advantage of their labour and strength in their better days, and to provide residences for them in his immediate neighbourhood, that he might have the value of their labour.

Referring to the repeal of the Corn Laws, Denison warned the farmers that they would have to wake up and attend to the question of labour and the conditions of the labourer, who often had to walk four or five miles to his work in the morning and return as many every night. It was a hardship they would not impose upon their cart-horses. Could they expect to draw from men a degree of labour which they knew was impossible to be obtained from horses? He respected the parochial system, but circumstances had changed. A free circulation of labour was necessary to equate supply and demand. "Though the parochial system might induce persons to act with kindness towards the poor, it led to such acts as the demolition of property." The union system would be cheaper, since there were over 14,000 parishes and only 623 unions, and the expenses of removals would be greatly reduced if a system of settlement by union were established, instead of settlement by parishes as then prevailed.

Denison told the House in conclusion that the proposal he had made would prevent the proprietor of land over which he had exclusive control from turning away his labourers. He thought such restriction was right. He was himself an owner of close parishes. He could therefore claim to be free from any imputations of personal motives in bringing this question forward. If the House approved his proposal, he said, they would remove that power from their hands; if not, they would leave him a power which he hoped he should not be disposed to abuse; but he should be glad to be deprived even of the temptation to do wrong. ${ }^{7}$

Denison's speech made a significant impression: propositions contained in the Instruction, similar to those previously rejected, now appeared to be more acceptable to a large portion of the House. As Graham noted in supporting the Instruction, the eyes of some members were open to the extreme hardship which would fall on many persons if they were only irremovable from a particular parish. The question had become one not only between the interests of manufacturers and rural districts, but a question concerning the comforts and feelings of the poor themselves.

It was not to be expected, however, that the county members, like the

${ }^{7}$ Hansard, Third Series, LXXXVII, cc. 44-51. 
French nobles in the Assembly of 1789 , would leap to their feet in turn and renounce their privileges. They were content enough with the Bill, for in times of slump it would prevent masses of workers from being returned from the manufacturing towns to the rural areas of their origin. Furthermore, now that the manufacturers had gained their way over the repeal of the Corn Laws, they would not oppose the Bill even though it would throw a big burden on them. But in the ensuing debate on the Instruction, though more evidence was forthcoming in support of it, county members continued to treat it as an attack on the much cherished parochial system, and maintain that the poor would suffer if it were adopted. Finally, when the House divided on Denison's Instruction, the voting was 92 to 70 in its favour. ${ }^{8}$ The Poor Removal Bill would now have to be remodelled so as to incorporate the Instruction. But, before the new Bill could be introduced; Peel's Government had fallen.

A Whig Government was formed and on 13th July 1846, soon after taking office, Lord John Russell, the new Prime Minister, announced that the Poor Removal Bill would go forward. It was intended, however, to leave out that part of the Bill relating to union settlement. This would become the subject of enquiry in that or the following session. County members naturally expressed satisfaction over this. ${ }^{9}$ On 16th July Sir George Grey, the Home Secretary, introducing the Bill, confirmed that Denison's part of it would be waived and that in the next session he would move for a Select Committee on the subject. Referring to the existing system as "shocking to the feelings of every just and humane man", he said he intended to proceed with that part of the Bill which gave irremovability after five years residence.

Vernon Smith, member for Northampton, spoke of the Home Secretary's gallantry "in covering with his shield the mangled remains of the Bill which had been bequeathed to him". A Select Committee, he said, would delay legislation for a long time. The Bill would induce the close parishes to throw their poor upon adjoining parishes. There were clearances in England as well as Ireland, he said. They had got free trade in corn, and now he wanted to see free trade in labour. ${ }^{10}$

Some members wished to have the Bill postponed, saying that it would aggravate the evils to which the poor were subjected. Poulett Scrope, a noted authority on the subject, asserted that the principle of the Bill was to relieve the rich parishes under the command of one or two wealthy pro-

8 Ibid., cc. 51-102, 6 June.

9 Ibid., cc. 1069-71.

10 Ibid., cc. $1210-12$. 
prietors, and to throw the expense of maintaining the poor on the poorer parishes. The Home Secretary might intend to remove the injustices in a future session, but Scrope was not sure he could do so, for those who had the power of relieving themselves from chargeability might maintain it. ${ }^{11}$

Other members, while dissatisfied with the Bill in its truncated form, supported it on grounds of humanity, believing it to be at least a step in the right direction. It was they who, with the County members, enabled the Bill to pass its third reading in a thin House. ${ }^{12}$ The Lords debated the Bill only once, at a brief second reading. It received the Royal Assent on 26th August (9\&10 Vict., c. 66).

When Parliament reassembled in 1847, it was already clear that the Poor Removal Act of the previous session was having seriously harmful consequences and had aroused widespread opposition. Not only were the proprietors of close parishes substantially freed from bearing the burden of much of the pauperism which had previously been theirs, but they were further encouraged to clear their estates of poor persons by the destruction or non-repair of cottages, for the new statute accorded to the close parish of settlement, permanent protection against removal of its settled poor from any neighbouring place in which they might have resided for five years. ${ }^{13}$

In the towns, too, the Act had given rise to great difficulties and hardship. A practice had grown up whereby parishes paid non-resident relief to their settled poor living elsewhere, thus providing a happier alternative to poor removal. The Act had not intended that this class, a numerous one, estimated at more than 82,000 persons, should acquire irremovability in the places where they resided, but it had been ambiguously drafted, and did not make clear whether this provision was retrospective or not. Being advised by the Poor Law Board that it was not, many Boards of Guardians stopped the non-resident relief they had been paying, thus bringing about an increase in the burden of pauperism in many towns. In addition, numerous persons who had not hitherto applied for relief for fear of being removed now did so. ${ }^{14}$

In the Commons the Act was widely condemned. It was said to be doing great mischief throughout the country: it had inflicted cruel injury on the poor; it was causing endless litigation; and there was a demand for its repeal. In the face of these complaints, Lord Russell moved for the appointment of a Select Committee to enquire into the law of settlement.

11 Ibid., cc. 1386-87.

12 The voting was: Ayes, 56; Noes, 9; Majority 47. Hansard, LXXXVIII, c. 216, 30 July.

13 R. Pashley, Pauperism and the Poor Laws (London, 1852), p. 281 ; A. Redford, Labour Migration in England, 2nd ed. (Manchester, 1964), p. 128.

14 S. and B. Webb, The Last Hundred Years, op. cit., pp. 422-23. 
The Home Secretary added that it should be an Instruction to the Committee to enquire first into the Poor Removal Act. ${ }^{15}$

On March 2nd, the day the Committee's report on the Poor Removal Act was printed, the latter was discussed in the Commons. Mr Bankes, member for Dorsetshire, and one of the Committee's leading members, confirmed what had previously been "charged against the Act: that it was working injuriously throughout the kingdom, to the ratepayers and, worse, towards the poor. Evidence showed that the Act operated most harshly against the old and infirm. Though a divergence of opinion existed among members of the Select Committee, one proposition had the approbation of many: union settlement. Some members agreed that the Act was a great evil and demanded its repeal, though others, including Sir James Graham, claimed that the Act itself, if interpreted and carried out as intended, was just and humane: it only required to be coupled with an alteration to the law of settlement. ${ }^{16}$

Matters could not be left as they were. Though certain categories of poor were now irremovable, the burden of local taxation had been thrown out of balance. Wealthy country landlords had been allowed to escape and were comparatively free from paying their share of poor rates, while there had been grievous pressure on towns, and especially upon the more humble ratepayers. They had become subject to a double rate: for the relief both of their own settled poor and of the newly irremovable resident poor with settlements elsewhere. In fact, the poor in many cases had to maintain the poor. Only a change in the law of settlement could remedy this state of affairs but, in a Parliament in which the landed interest was so strongly represented, the Government were in no hurry to bring in a Bill. The appointment of a Select Committee had been adopted simply as a delaying device. Mr Bankes, however, was not prepared to wait, and in June he introduced into the Commons a bill to amend the Poor Removal Act. It was not successful, but it provided an opportunity for members to report further on the working of the Act and to give expression to developments in public opinion.

Mr R. Palmer, member for Berkshire, described how harmfully the Act had operated during the previous winter to those residing in towns but whose labour was bestowed on adjoining agricultural parishes. A striking

${ }^{15}$ Hansard, LXXXIX, cc. 320-34, 22 January 1847. The Committee, when appointed, was composed of seven members from one side of the House and eight from the other. They were from different parts of the country and represented town and rural areas fairly, and included those who had made a special study of the subject and were recognised authorities on it.

${ }^{16}$ Hansard, XC, cc. 707-21, 2 March. 
illustration was that of Reading. People were not relieved in parishes where they were employed because they were not resident in them - and in Reading they were refused also, on the ground of having no legal settlement there. The Marquess of Granby, who sat for Stamford, told how the Act had been of benefit to the close but not to the open parishes. In Grantham, he said, forty families had been removed from one parish to the neighbouring parish while they still continued to labour in the former parish, but where they could no longer reside because their cottages had been pulled down. Had their families become destitute they would have been a burden on the liberal parish which had received them, to the sole advantage of the close parish which had sent them away.

The Home Secretary spoke of the widespread opinion that the law must be changed extensively; and one of the changes, he averred, ought to be an extension of the area of rating. Sir James Graham supported him in this. The most authoritative statement of all came from Charles Buller, President of the newly formed Poor Law Board, and himself chairman of the Select Committee, when he told the House of "the growing opinion of the country $-[\ldots]$ the growing wish that the area of rating should be extended". 17

The intolerable situation was tackled by W. H. Bodkin, ${ }^{18}$ member for Rochester, who produced the Poor Removal Act Amendment (No 2) Bill. This was supported by the Government and passed through both Houses in little over a fortnight, ${ }^{19}$ encountering remarkably little opposition. By its terms, the cost of relieving those whom the Poor Removal Act had made irremovable was to be borne by the union and not by the parish in which the said irremovable persons resided.

No doubt what eased its passage through Parliament was the very limited nature of its aims. It appeared to offer a reasonable solution to a pressing social problem with the minimum of disturbance of the existing system, for establishment costs - workhouse, salaries of officials, etc. were already being borne by the union. Payment of the new union charges would be made by the constituent parishes in proportion to their average Poor Law expenditure over the previous three years. It was, perhaps, not recognised at the time that the development represented by Bodkin's Act was a significant breach in the parochial system; and one which in the future could and would be extended until the system itself became undermined.

17 Hansard, XCIII, cc. 647-48 and 826-34, 16 and 23 June.

18 Described by the Webbs as a lifelong student of Poor Law administration. A successful barrister, was an MP from 1841 to 1847 . The Last Hundred Years, p. 423, note 2.

19 Commons second reading, 8 July; Royal Assent, 23 July (10\&11 Vict., c. 110). 
While Bodkin's measure was in process of passing through Parliament, the Select Committee on Settlement and Removal presented its findings in the form of nine resolutions.

1. Resolved: that the Law of Settlement and Removal is generally productive of hardship to the poor and injurious to the working classes, by impeding the free circulation of labour.

2. Resolved: that it is injurious to the employers of labour and impedes improvement of agriculture.

3. Resolved: that it is injurious to the ratepayers, by occasioning expense and litigation and the removal of paupers.

4. Resolved: that the power of removing destitute poor persons from one parish to another in England and Wales be abolished.

5. Resolved: that as the total abolition of the power of removing persons within England and Wales would have the effect of greatly increasing the burthens of particular parishes, it is advisable that some change should at the same time be made in the distribution of the burthen of relieving the poor.

6. Resolved: that the narrowness of the area of chargeability is one great source of the evils above adverted to, as well as of others arising from the interest of landowners and ratepayers in preventing residence within that area of persons likely to become chargeable.

7. Resolved: that it is therefore desirable to extend the area of rating for the relief of the poor.

8. Resolved: that unions would form the fittest area for that object.

9. Resolved: that with a view to rendering the working of a system of union rating more just and equal, it would be advisable to facilitate, in certain cases, the alteration of the limits of existing unions in England and Wales. ${ }^{20}$

Here were resolutions made after due deliberation by a committee containing expert and experienced opinion strengthened by a wealth of evidence. Parliament now had at its disposal the data on which to base much-needed reforms. Whether it would take effective action was another matter.

\section{II}

As Bodkin's Act (10\&11 Vict., c. 110) was due to expire in October 1848, its main provisions were to be contained in the Poor Law Union Charges (No 2) Bill, which Charles Buller introduced into the Commons in the preceding July. The new Bill added vagrants to the charge of the common fund of the union. Also, it contained a clause introducing an important innovation. Whereas, in Bodkin's Act, charges for the irremovable poor (as well as establishment charges) were made for each parish in proportion to the

${ }^{20}$ Select Committee on Settlement and Poor Removal [Parliamentary Papers, 1847, XI). 
average expenditure on poor relief during the three years preceding the passing of the Act, Buller proposed in his Bill a system less manifestly unjust: to provide for a uniform contribution. This was to be assessed, not in reference to past payments, but on the rateable value of every parish.

In pressing for the adoption of this clause, Buller warned the House that resistance to his suggested reform might bring all their old institutions about their ears, by raising up a feeling in the community that would lead to changes being applied rashly and hastily. He noted the growing feeling in the House, and also among boards of guardians and in the country at large, against the parochial system and in favour of an extension of the area of chargeability and of union rating. He therefore urged the acceptance of his system of modified or partial union rating, for if it were rejected the alternative might be the adoption of national rating, which would do away with all local control. ${ }^{21}$

The case for Buller's reforms would appear to be unexceptionable, but as their adoption would result in the close parishes having to contribute a greater share of poor-rate burden than hitherto, the county members rallied to oppose them. Their spokesman was again J. W. Henley, member for Oxfordshire, ${ }^{22}$ who based his opposition to the projected changes on the grounds that they would lead to increased expenditure on poor relief, and would break down the whole parochial system and lead to the imposition of a national poor rate. ${ }^{23}$ Henley was supported by other county members using similar arguments. The debate dragged on until, on 28th July, Buller had to tell the House that though he had country-wide support and believed he should obtain the general assent of all parties to the passing of his Bill, its opponents were able to wield one power which was irresistible at that period of the session - the power of time. As it was absolutely necessary to renew Bodkin's Act of the previous session, he would cut out the provisions regarding union contributions assessed on the rateable value of constituent parishes. ${ }^{24}$ The country gentlemen had had their way once more, and though there were some expressions of dissatisfaction at the rich evading their duty of supporting the poor, the Bill passed through all its stages by 9th August (11\&12 Vict., c. 110). Buller died unexpectedly in November 1848, though not before he had taken steps to strengthen the case for reform by setting up a Poor Law Board enquiry into

21 Hansard, C, cc. 787-801, 25 July.

22 Although the very model of a country gentleman, he was the son of a London merchant. He affected to embody the traditional virtues of the squirearchy. Platitudinous and longwinded, he was dogged and untiring in defence of his own viewpoint.

23 Hansard, C, cc. 801-03.

24 Ibid., cc. 924-25. 
the laws of settlement and removal. Its reports were not laid before Parliament until early in $1850 .^{25}$

Meanwhile, the Government did nothing further in the matter. It was a subject they would tend to shun, for while the improving of the pauper's lot could bring them little political credit, those who might believe themselves to be adversely affected by the changes were powerful and influential. Nevertheless, members of both Houses continued from time to time to draw attention to the need for reform. In February 1850, Poulett Scrope introduced a measure to have the poorest kind of cottages exempted from rating. In his speech he quoted evidence given before the 1847 Select Committee, of the profound evils resulting from the inadequacy of cottages. In the Southern counties, where population had been rapidly increasing, cottages were absolutely decreasing in number. Scrope claimed that the law of settlement operated powerfully as an inducement to owners and occupiers of land in the smaller parishes to prevent the residence there of poor persons. He wanted the Government to extend the area of rating and settlement from parishes to unions, so as to put an end to the strong motive to the clearance of parishes. The House was hostile, and he was shouted down at times, a reaction, as he himself observed, not surprising in a Parliament composed mainly of landowners and ratepayers. His motion was negatived. ${ }^{26}$

In the same month Disraeli initiated a full-scale debate on the prevailing agricultural distress. He proposed that establishment charges, as well as the cost of maintaining and providing for the casual poor and several other charges not concerned directly with poor relief, should be defrayed out of the general taxation of the country and not by poor rates. This would relieve the landed interest of over $£ 2,000,000$ per annum of their poor-rate burden, which was the amount of a current budget surplus. Though Disraeli was extremely persuasive - even Gladstone voted with him for his proposition - , he failed by a narrow margin to carry his motion, probably because many feared that if he gained this measure he would go on to revive protection.

The important feature of the debate was the opportunity it provided for considering the position of the labourer vis-a-vis the system of rating and the laws of settlement. Sir James Graham, though opposing Disraeli, echoed the latter's central principle, that the possession of wealth and property was based on the performance of social duty.

25 Reports to the Poor Law Board on the operation of the laws of settlement and removal of the poor [PP, 1850, XXVII].

26 Hansard, CVIII, cc. 471-79. 
I have always told them [the country gentlemen] that as a class, with the community at our back we are irresistible [. . .]; but that on the other hand, if we as a class pursue our exclusive interests at the expense of the general interests of the community, we are altogether powerless, and our overthrow is certain.

Quoting Adam Smith on the injustice of the law of settlement, he stressed the importance of redistributing and equalising the burden of the poor rate by revising the law of settlement, substituting union for parish settlement and thereby greatly increasing the circulation of labour.

Sir Robert Peel drew the attention of the House to the Poor Law Board reports, which had just then become available. These showed that, because of the operation of the law of settlement, the want of cottage accommodation in areas of close parishes compelled labourers to walk several miles to and from their work each day. Though members laughed when Peel spoke of donkeys being employed to transport labourers, he insisted on Parliament considering seriously that many labouring men had their strength exhausted by the length of the distance they had to travel to their work. And there were others forced into adjacent villages where they paid high rents for small and imperfect houses. ${ }^{27}$ Not all members found the plight of the labourers a fit subject for merriment; and over the following years attempts were made in the Commons and the Lords to initiate legislation through Private Members' Bills. ${ }^{28}$ The Government promised its own legislation, though for several sessions, because of "pressure of public business" none was forthcoming.

1852 saw the publication of two important works: James Caird's English Agriculture in 1850-51, and R. Pashley's Pauperism and the Poor Laws. Caird showed, inter alia, that in a number of counties, the evils attaching to open and close parishes were much in evidence: open parishes paying heavy poor rates and close ones adjoining paying light ones, due to the latter allowing no cottages to be erected and diminishing existing ones, so casting off their labourers upon their unfortunate neighbours. Other consequence of settlement law included the long, wearing walk by the labourer to and from his work, and the labourer not being free to carry his skill to a better market except on terms felt to be prohibitory. ${ }^{29}$ Pashley represented

27 Ibid., cc. 1026-103 and 1189-264, 19 and 21 February.

2824 July 1850, Commons, R. A. S. Adair, Poor Relief (Cities and Towns) Bill; 6 May 1851, Commons, Grantley Berkeley, Poor Rates - for an equalisation of Poor Rates throughout England and Wales, and subject to local government; 15 April 1853, Lords, Lord Berners, Poor Removal and Local Assessment Bill; 26 July, Commons, Apsley Pellatt, Poor Removal. In addition, numerous questions were put and petitions presented during this period (1850-54) as well as notices of Resolutions.

29 Op. cit., pp. 7-8, 75-76, 84-86, 197, 202, 223, 515-18. 
the existing law, 9\&10 Vict., c. 66 , as one which took the burden from the shoulders of the country gentlemen and placed it, first on the town parishes, and then, after the passing of Bodkin's Act, over the wider space of the town unions. The burden had in fact been transferred from the agricultural to the town interest. The system produced inequality in the incidence of the poor rate, diminishing the burden where it was light and increasing it where it was heavy. He maintained that the poor-rate charges ought to be imposed on the property and not on the poverty of the several parishes of the union. He proposed the abolition of the law of settlement; an extension of the area of chargeability; and that the poor rates should be based on the principle of rateable value. Both publications were influential and undoubtedly affected educated opinion, while the Private Members' Bills, though not successful, had the effect of so publicising the subject that the Government was eventually impelled to act.

In February 1854, M. T. Baines, President of the Poor Law Board, introduced a "Settlement and Removal Bill" into the Commons. It embodied the recommendations of the Commons Select Committee of 1847 and those of the Poor Law Board enquiry that followed, and had two main objects. One was to abolish "the power to remove a poor person on the ground of settlement, from one parish in England and Wales to another". The second was to take the union instead of the parish as the area of chargeability, ensuring that all the rateable property within the union should contribute, according to its value, to the union's total poor-law expenditure, so that there would be an equal and uniform rate of contribution throughout each union, as there was then throughout each parish. ${ }^{30}$

Baines's proposals were received very favourably. Both The Times and the Morning Post warmly supported them. ${ }^{31}$ Yet the country members had evinced some hostility, and Irish members were already demanding that freedom from removal should be extended to Irish paupers. It was this issue which was to destroy the Bill. At the second reading, Lord Claud Hamilton, member for Tyrone, told the House that, after the Bill's first reading, 67 Irish members had signed a memorial requiring the Government to provide Irish paupers with the same right of freedom from removal as was proposed for the English. Lord Palmerston, then Home Secretary, to whom the memorial had been presented, later informed the memoralists of the Cabinet's agreement that their wishes should be complied with. This information was something of a bombshell and the debate soon ended. ${ }^{32}$

30 Hansard, CXXX, cc. 443-84.

31 The Times, 11 and 13 February; Morning Post, 13 February.

32 Hansard, CXXXI, cc. 1274-336, 24 March. 
Upon its resumption a few days later, Baines stated that it was not advisable to mix the Scotch and Irish question with that of England. The latter question had been left perfectly clear by enquiries and reports, while that of Ireland and Scotland required further investigation. The House, he said, should proceed with his Bill, leaving the Irish issue to be settled later. ${ }^{33}$ However, the Irish members would not agree to this course, $\mathrm{Mr}$ Maguire saying bluntly that if they allowed the Bill to pass, the Irish members would forfeit all their influence on the question, and would have no such power to put the screw on the Government as they had then. The debate was postponed until 30th March, when Baines told the House that the Cabinet had not even informed him of the memorial and their reply to it. He had been "hurt and mortified" and had almost resigned..$^{34}$ By this time it was clear that the Irish members would not allow his Bill to pass independently of the Irish issue. On 2nd May, Lord Aberdeen, the Prime Minister, announced that a Select Committee of the Commons had been appointed that day to enquire into the state of the law affecting the removal of the Irish and Scotch poor, and that, until it reported, Baines's measure would be suspended. ${ }^{35}$ In the event it was abandoned when the Crimean War brought about a change of Government in January 1855.

The Select Committee did not report until June 1855, but, again, "pressure of business" prevented legislation being brought forward until 1st April, 1856, when Mr Bouverie, the then President of the Poor Law Board, introduced the Scotch and Irish Pauper Removal Bill. ${ }^{36}$ There was much opposition to it in the metropolis, in the manufacturing districts, in Scotland and, surprisingly, in Ireland too. Apparently the English thought it went too far, the Irish, not far enough. There was no chance of carrying it and it was withdrawn in June.

\section{III}

A new factor in the struggle for rating reform was the emergence of an organisation first known in 1855 as "The Metropolitan Association for the Abolition of Poor Removals and the Equalisation of Poor-Rates". In 1857 it had become "The Association for Promoting the Equalisation of PoorRates and Uniformity of Assessments throughout the Metropolitan Dis-

\footnotetext{
33 Ibid., cc. 1353-71, 27 March.

34 Ibid., CXXXII, cc. 72-75.

35 Ibid., cc. 1184-85.

36 Ibid., CXLI, cc. 309-14.
} 
tricts". It sought to influence public opinion by publishing pamphlets, ${ }^{37}$ by holding public meetings, organising and presenting petitions to Parliament and providing evidence before Parliamentary Committees of Enquiry.

The drift from rural areas to the metropolis was now constituting a serious social problem, as more and more of the poor crowded into the poorer parishes, usually those in the East End. The unfortunate situation vis-a-vis open and close parishes in the country at large had its counterpart in London, where the poor rates were heaviest in the poorer parishes and lightest in the richer ones, and for much the same reasons: each parish was responsible for the relief of its own poor; rich and poor tended to live each within their own areas; the former were able to prevent the latter from residing in their areas. In 1857 matters had reached a low ebb in the poorer parishes, and letters were appearing in The Times, telling of ratepayers who had been compelled to pawn their goods to pay the rate collector; of suicides due to stark want; of men parading about the streets in a menacing manner; and of bakers' shops broken open. The writers were Anglican clergy from the poorer parishes, and they were demanding equality of rating throughout the metropolis in order to put an end to these evils. It was they, too, who formed a deputation to meet the President of the Poor Law Board, though with little effect. ${ }^{38}$

At this point their cause was taken up by A. S. Ayrton, Liberal member for Tower Hamlets, who had entered Parliament in 1857 for the first time. ${ }^{39}$ Ayrton possessed great ability and was known for his conspicuous independence of character. In moving for a Select Committee to enquire into the causes of the inequality of poor rates in the metropolitan districts, ${ }^{40}$ he told the House plainly that some members were afraid to touch that subject because they apprehended it would lead to investigations over a large area under circumstances that would be prejudicial to the landed interest. To allay these fears he undertook to confine his question to the metropolitan area. But in the debate that followed it was said that if reforms were made in the London area, reforms would be demanded over the rest of the country. And, as a supporter of Ayrton observed, at the very thought of an

37 Observations on the Laws of Settlement, Poor Removals and the Equalisation of Poor Rates, etc. (1855); Address from the Association to the Ratepayers, etc. (1857); The Poor Laws - as they are and as they ought to be (1861). Its range of interest had widened, as shown by its change of title, which had now become "Metropolitan and County Association for the Equalisation of Poor Rates".

38 The Times, 12 February, 14, 15, 20, 23 and 30 April, 5-8 and 25 May 1857.

39 Acton Smee Ayrton (1816-86) was a barrister; MP, 1857-74; Parliamentary Secretary to the Treasury, 1868-69; created Privy Councillor, 1869; First Commissioner of Works, 1869-73; Judge-Advocate-General, 1873.

40 Hansard, CXLV, cc. 1899-935, 16 June 1857. 
equalisation of poor rates throughout the country "a feeling of horror appeared to pass through the minds of all the country gentlemen". ${ }^{41}$ Ayrton argued his case with force and cogency, but though he received a fair measure of support, he was opposed by the President of the Poor Law Board and by the Chancellor of the Exchequer, among others. His motion was defeated.

Ayrton returned to the fray in 1858, introducing his Poor Rates (Metropolis) Bill. Its objects were to enlarge the area of rating and bring about equalisation of poor rates throughout the metropolis. The bill was debated at length, ${ }^{42}$ but at the second reading, when it was made clear to Ayrton that, in spite of all he and his supporters could say to impress upon the House the scandalous evils of the existing system, the majority would be against his measure, he agreed to withdraw it. Opposition to it had been based - ostensibly - on the necessity for local supervision of local funds. It was the usual argument. Equality of rating, it was maintained, would lead to centralisation, a national poor rate with all the resultant carelessness and extravagance that this implied.

But were these the real reasons for the rejection of the measure? In this connection it is important to note that in the course of the debate, Ayrton, who was notoriously outspoken, had challenged members to support the cause of social justice by taking a step which would increase their own expenses, inasmuch as they resided in those very districts of the metropolis upon which he sought to impose a fair share of the burdens incurred for the maintenance of the poor. As we saw, the House had not responded. There can be little doubt that he was close to the truth of the matter when, on a later occasion, he complained to the House that no really effective reform of the Poor Law had taken place for the past twenty-five years because of the opposition of the territorial aristocracy, who feared that the changes which were necessary might have a serious effect on their pecuniary interest, an effect, he said, which would be felt by the wealthy within the limits of the metropolis as well as by persons of that class living elsewhere. This question, he claimed, was one between a great mass of people and a numerically small proportion of the population; but the latter was so influential that the President of the Poor Law Board, like every other Minister of the Crown, could not - or dared not - meet the real issue. ${ }^{43}$

After the failure of his Bill he had intended to bring in another; but, instead, he elected himself on to every Poor Law Select Committee of the

41 J. Locke, ibid., CXLIX, c. 639, 23 March 1858.

42 Ibid., cc. 626-48, and CL, cc. 496-516, 23 March and 12 May.

43 Ibid., CLXI, cc. 236-39, 8 February 1861. 
Commons between 1858 and 1864 , and was thus able to influence the course of legislation in the direction he desired.

IV

In July 1859, C. P. Villiers ${ }^{44}$.became President of the Poor Law Board, with a seat in the Cabinet. His interest in Poor Law affairs was of long standing, for he had taken part in the great Poor Law enquiry of 1832-34; and since that time he had sat on every important Commons Committee of Enquiry into the operation of the Poor Law. He was therefore well equipped for his new post and was to become a notable reformer. Like his predecessor Charles Buller, he entered Parliament as a Radical and, like him too, he was to find that the county members were the most determined opponents of his Poor Law reforms. It had been said of Buller that he took "a special pride in girding at the county members in particular", and that he was "rather sharp on the country gentlemen, dealing them severe hits" 45 in the course of debate. Villiers, too, had encountered their hostility during his earlier days as a free-trade pioneer, when they "came [into the Commons] half drunk to silence by their unannerly cries, the representatives of the manufacturing and commercial interests" ${ }^{46} \mathrm{He}$ was to encounter it again.

His first major legislation, the Irremovable Poor Bill was introduced into Parliament on 28th June 1861. It was founded on the conclusions of a Commons Select Committee, after an enquiry extending over three sessions, into the operation of Sir Robert Peel's Poor Removal Act of $1846 .{ }^{47}$ The Enquiry had been called for because this Act had continued to cause widespread complaint, and was said to be much more unfair and unequal than could ever have been contemplated by Parliament. The unsatisfactory features were now to be rectified by the new measure, which had three main objects: to reduce the period of residence for acquiring a status of irremovability from five years to three; to make the union the place of residence instead of the parish only; and, most significantly, - by the 9 th clause - to improve the mode of raising the common fund by assessment on the rateable value of all parishes in the union. The Bill's aims, therefore, were limited compared with Baines' more radical measure of 1854 .

44 Charles Pelham Villiers (1802-98), grandson of the first Earl of Clarendon; secretary to the Master of the Rolls, 1830; Assistant Poor Law Commissioner, 1832-34; MP for Hull, 1835-98; Judge-Advocate-General, 1852-59; President of Poor Law Board, 1859-66.

45 London Illustrated News, 24 December 1842.

46 Manchester Times, quoted by W. O. Henderson, "Charles Pelham Villiers", in: History, New Series, XXXVII (1952), p. 29.

47 9\&10 Vict., c. 66 , modified in 1847 and in 1848. 
In commending the Bill to the House, Villiers adopted a conciliatory tone. ${ }^{48}$ It did not, he said, introduce any new principle, but was simply to give greater effect to a very beneficial measure, Sir Robert Peel's Poor Removal Act. He explained that when the irremovable and other classes of poor were charged upon the common fund of the union, it soon became evident that the principle upon which the common fund had been raised was not applicable to the new charges then cast upon it. From that time onwards there had been an outcry that the fund should in consequence be maintained by a rate on the property of the union and not, as heretofore, on the particular parishes varying according to their previous expenditure on their own (settled) poor. There was clearly no just or intelligible ratio in determining by those means the proportion that the parishes ought to contribute to the common fund. They could not by their management control the numbers of irremovable poor that resided in a union; and to call upon them in proportion to their poverty on another account was almost ludicrous as well as arbitrary. The practical object of the Bill, said Villiers, was to meet that grievance, which was felt more or less in every union in the country.

He indicated how the charge for the relief of the poor fell very unequally upon parishes, providing examples of this from both town and country. The Bank of England, for instance, stood in a parish in which there were no poor, and therefore contributed nothing to the common fund. Again, in the parish in which St Katherine Docks were situated, there were hardly any poor, the space being nearly all occupied by the docks, but the neighbouring parishes where the labourers swarmed, most of whom worked in the docks, had not only their own poor to support, but on account of their own being numerous, had a much larger contribution to make to the common fund in support of the poor of other parishes. In rural areas, there was the anomaly of wealthy proprietors who might own, or with two or three others possess, a whole parish, and, by getting their labourers from other parishes, could not only escape all charge for any poor but their own, but also for any liability at all for the poor charged upon the common fund. The Bill, he said, would adequately meet these injustices. It was extremely moderate, and should it be rejected he begged them to remember there was an organised movement in favour of a general and immediate equalisation of rates throughout the whole country and they would act wisely in not giving strength and energy to such a movement. ${ }^{49}$

Villiers was supported by the Home Secretary, by Sir James Graham,

48 Hansard, CLXIV, cc. 28-30.

49 Villiers considered this pressure group sufficiently impa tant to bring it to the notice of the House. 
and by others. The House accepted the first two clauses, being prepared to mitigate the evils of poor removals and the injustice of settlement. But a big fight developed over the 9th clause. Again the county members were its chief opponents, for they were aware that, should it pass, many landowners would no longer remain exempt from any contribution for the union poor. They fought vociferously and at length against this clause, using all their old arguments to demonstrate the so-called evil consequences that would result from its passing. Henley spoke of the injustice involved in the "shifting of burdens" in taxation. Also, he said, the country did not have enough information on which to base an adequate judgement, for they were all "in the dark" about how the tax changes would affect it, parish by parish. Villiers, writing privately at this time to the Duke of Newcastle briefing him for the passage of the Bill in the Lords, ${ }^{50}$ said: "There is no kind of information connected with removal and settlement and union rating that is not now in Blue Books in one or other of the Houses, and the people who oppose the Bill understand it perfectly - they have only too much information for their book!" In another letter he wrote:

Sir John Pakington made a proposition to me to support it [the 9th clause] if I would insert a clause to exempt extra-parochial places. I told him I could not support his clause, but if the House chose to do so I would adopt it. The House negatived the clause and Sir John would not support the Bill! The Duke of Rutland has property of this kind, and Lord John Manners ${ }^{51}$ supported Pakington and then voted against the Bill - so much for the chivalry of that medieval lord!!52

The exemption of extra-parochial places from contributing towards poor relief had been ended by 20 Vict., c. 19, passed 21 st March 1857. "What is the difference", asked Villiers, "between an extra-parochial place then [before the exemption ended], and a close parish now?" Regarding an often-repeated charge he pointed out: "This Bill does not $[\ldots]$ do what they say - disturb the Parochial 'system'. That was all done first by Sir Robert Peel's plan in 1846, and by Buller's Act much more effectively in 1848." He wrote of the infinity of trouble he had had with the Bill. It was brought in the previous February and had been submitted to the different Boards of Guardians throughout the country. At least eighteen out of twenty had approved of it. There had been upwards of seventy petitions presented in its favour - "and it has been under discussion for three weeks and upwards in the House - every endeavour having been made to talk it

50 Letters on Irremovable Poor Bill from C. P. Villiers to Duke of Newcastle, July 1861 , University of Nottingham, Department of Manuscripts.

51 Son of the Duke of Rutland.

52 Reference to Young England. 
out." 53 The latter was a real danger for, as we saw, it was what had happened to Buller's almost identical clause in 1848. On the present occasion, however, the Government pressed on with the Bill, providing sufficient time, including late-night sittings, for the clause to be fully debated. A number of factious and time-consuming amendments were put forward, but they were finally defeated and, on 16th July, the 9th clause was agreed to by 127 votes to 44 , a majority of 83 .

A week later the Bill was presented in the Lords. Sir James Graham had said positively that it was a money Bill and Villiers had advised the Duke of Newcastle to let the Lords know this. ${ }^{54}$ There was little opposition, however, the constitutional position was not publicly raised, and the Bill passed through all its stages by 1st August (24\&25 Vict., c. 55).

As the Bill had brought about a sort of revolution in the whole system of parochial rating, the need for uniform and correct valuation and assessment of property became imperative. Poor rates had their origin in the 43rd of Elizabeth and there had been little legislative change thenceforward. With the passage of time various anomalies had developed, and grossly uneven rating existed in a great many parishes. ${ }^{55}$ These irregularities had engaged the attention of Parliament for many years without effective legislation reaching the Statute Book.

Many reasons have been advanced for this unfortunate failure on the part of Parliament. It has been suggested that most MPs were ignorant of the technicalities of rating law, which bored them with its dry, tedious and excessively complicated nature. ${ }^{56}$ Yet Parliament itself included many substantial ratepayers who would be affected by changes in the law and had reason to be interested. Expert testimony on the nature and causes of the contrasts and inconsistencies in valuations, while indicating that these were not solely due to incoherent developments of the preceding centuries, pointed to reasons for their long-continued existence. A most significant piece of evidence was provided by W. G. Lumley, Secretary of the Poor Law Board, before the House of Lords Select Committee appointed in 1850 to consider the laws relating to parochial assessment. He stated that the rental in many cases was a very false criterion of its real value; that in numerous cases property was assessed well below its true rateable value. ${ }^{57}$

${ }^{53}$ From its Committee stage, the Bill's progress in the Commons is reported in Hansard as follows: CLXIV, cc. 402-10, 799-800 and 967-76, 5, 9 and 16 July.

54 Villiers to Duke of Newcastle, ibid.

55 For example, Spitalfields $4 / 21 / 2 d$ in the pound, and the Minories $7 \frac{1}{2} \mathrm{~d}$; St John's, Bedford, 2/1/2d, and St Mary's, an adjoining parish, 4d. The Times, 8 March 1862, quoting Poor Law Board Report on Rating 1855-56.

${ }_{56}$ R. Blake, Disraeli (London 1966), p. 464.

57 House of Lords Select Committee on Parochial Assessment [PP, 1850, LVI], q. 284. 
According to the Duke of Newcastle, the differences between real and rateable value in many parishes amounted to as much as $20 \%, 30 \%$ and even $50 \%{ }^{58}$ Villiers had said that among the chief causes of blatant irregularities in valuations were influence and interest. ${ }^{59} \mathrm{~W}$. Deedes, member for Kent East, had noted that it was in the rural areas that great discrepancies occurred. ${ }^{60}$ All these factors implied that the existence of a corrupt rating system was in the interest of the landlords.

A Parochial Assessment Bill had already been introduced into Parliament in the session of 1861 . It was referred to a Select Committee, which came to certain resolutions respecting it, in consequence of which the Bill was redrawn. The session was, however, too far advanced for its being considered; and the committee recommended that if the Bill should be brought in in the session of 1862 and read a second time, it should again be referred to a select committee. This was done.$^{61}$ On the 27 th June, when the time was approaching for the Bill to be brought up in committee (of the House), the special concern of county members was indicated by Sir John Trollope's asking that the day fixed for the committee should be changed to one when many of the country gentlemen would not be attending Quarter Sessions. The sitting was accordingly deferred to a later period.62

In committee the Bill came under heavy attack from the country gentlemen, again led by J. W. Henley and supported by F. W. Knight, Sir Lawrence Palk, G. W. P. Bentinck and others. Failing to destroy the Bill by having it postponed, they fought it clause by clause, no fewer than four sittings being devoted to the committee stage. ${ }^{63}$ Numerous amendments were attempted and fresh clauses introduced. With the end of the session so near, Villiers, in charge of the Bill, was anxious to expedite its passing. Some of the amendments and additions he accepted; many were negatived. On 15th July the Bill had come through basically intact.

In the Lords the second reading took place on 24th July, and though the Bill met with some hostility and criticism, the Duke of Newcastle, leading for the Government, warned that changes made in the Bill at that stage would be a breach of the privileges of the House of Commons. It was thereupon read a second time without amendment. ${ }^{64}$ It passed through all the remaining stages without further debate, receiving the Royal Assent on

${ }^{58}$ Hansard, CLXVIII, c. 728, 24 July 1862.

59 Ibid., CLXVII, c. 1335, 3 July.

${ }^{60}$ Ibid., CLXI, c. 151, 7 February 1861.

${ }^{61}$ Ibid., CLXV, cc. 413-17, 17 February 1862.

62 Ibid., CLXVII, c. 1151.

63 The committee proceedings are set out in Hansard as follows: CLXVII, cc. 1330-35, CLXVIII, cc. 16-20, 234-40 and 344-48, 3, 8, 11 and 15 July.

64 Ibid., CLXVIII, cc. 728-31. 
7th August (25\&26 Vict., c. 165). By its terms Boards of Guardians were required to appoint committees to prepare lists of ratepayers and to assess the value of their property on which poor rates had to be payed. Thus, after a lapse of twenty-eight years, the valuation and assessment of rates were at last placed on a more equitable basis.

The winter of 1860-61 had been a bitter one, and there were widespread complaints over the failure of the Poor Law to cope adequately with the prevalent distress, especially in the metropolis. Other aspects of Poor Law administration were also being criticised, and in February 1861 the House of Commons appointed a Select Committee with broad terms of reference, to enquire into the operation of the Poor Laws. In April 1864 the Committee issued a wide-ranging report, which included the recommendation "that any measure for extending the area of rating should (in the opinion of the Committee) embrace provision for making the whole cost of the poor in each union chargeable on the common fund of the union". 65

Villiers sought to embody this recommendation in the Union Chargeability Bill, which he introduced into Parliament on 20th February $1865 .{ }^{66}$ On this occasion he made a brief survey of Poor Law legislation since 1834, noting how it had encouraged proprietors to create close parishes by driving away the poor, thus overburdening open ones, and showing the injustice which was inflicted on the poor themselves, as well as on the parishes, by the law of removal. To remedy these evils the new measure contained two main provisions. As the Irremovable Poor Bill of 1861 ( $24 \& 25$ Vict., c. 55 ) had resulted in $51 \%$ of total expenditure on the relief of the poor being charged to the union or common fund, the new Bill proposed to extend the system, so that all the expenditure on the poor - the remaining $49 \%$ - which was at this time a parochial charge should be cast on the common fund. The area of management would thereupon coincide with the area of rating. The Bill would also transfer the power of removal from overseers to guardians, which in effect would end all removal between parish and parish in the same union. J. W. Henley, who was later to play a leading role in opposing the Bill, challenged a number of Villiers's statements, though he did not then oppose the Bill's introduction.

On 27th March, Villiers moved the second reading. He was anxious to

65 Report of Select Committee on Poor Relief [PP, 1864, IX].

66 Hansard reports on the Bill occupy 346 columns! References are as follows: CLXXVII, cc. 468-86, CLXXVIII, cc. 277-358, CLXXIX, cc. 116-73, 303-71, 491-525, 663-702 and 789-800, CLXXX, cc. 9-42, 351-57 and 524-26; 20 February, 27 March, 11, $15,18,22$ and 25 May, 12,16 and 20 June, respectively. 
show that the Bill did not involve any new principle. The scheme of the New Poor Law was the substitution of the union for the parish as the basis for the management of the poor. It had also been intended that the union should supersede the parish for rating and charge. But in 1834, stated Villiers, there had been considerable alarm among the landed interest, the influential ratepayers who were afraid of having to contribute a greater share of the poor rate burden than they had formerly done. These persons were fully represented in Parliament and they succeeded in preventing the Commons from carrying out the plan they had in view, which was to do away with parochial liability, and to have union administration and commensurate union chargeability. The 1834 Act was launched, therefore, under the obvious disadvantage of being a combination of two systems that of the union and that of the parish. A provision existed in the Act by which the guardians, if unanimous, might have constituted a union into one parish for.financial purposes. The difficulty was that, as unions were constituted, there were generally one or two close parishes in them which had an interest in escaping the change and they were invariably able to prevent the unanimity required by the Act. The retention of the parochial system was the reason the act had failed in many respects.

Villiers enumerated the lamentable consequences of that failure, quoting evidence from past enquiries, from evidence contained in Caird's book, ${ }^{67}$ and from evidence given by Lord Malmesbury before a Committee of the House of Lords. ${ }^{68}$ Perhaps his most telling evidence came from a newly published report of a medical man, Dr Hunter, who had been commissioned the previous summer by the Medical Department of the Privy Council to enquire into the state of cottage accommodation throughout the rural districts of the country. This report connected the system of parochial settlement with the brutish living conditions in which the agricultural labourers and their families were too often to be found. It contained detailed accounts of the number of houses that had been pulled down in different parishes where, in many cases, the population had also increased and the motive for the pulling down of those houses was directly ascribed to the system of settlement. There were upwards of 800 parishes

\section{${ }^{67}$ Caird was now MP for Stirling.}

${ }^{68}$ Lord Malmesbury had observed that the anomaly of the parochial system was acknowledged, its most glaring effects being that the proprietors of close rural parishes could and did transfer their poor population to neighbouring parishes, thereby reaping all the advantage of their labour when efficient, without the responsibility of their maintenance when unable to work. "I do not think", he said, "I need make any observations upon close parishes. Your lordships are more aware than any other class of the community what they mean and how they work." House of Lords Select Committee on Parochial Assessment, Minutes of Evidence, $\$ 2399$. 
where the number of houses had diminished and the population had increased. ${ }^{69}$ In conclusion, Villiers added some observations in support of the principle of his measure, made by Sir Edmund Head, one of the three original Poor Law Commissioners of Somerset House. ${ }^{70}$

Sir Rainald Knightley opposed the Bill on two grounds - first because it would interfere with the rights of property and, secondly, because it would prejudice the interests of the labouring classes themselves. He moved an amendment: "That considering the little knowledge this House possesses as to the practical working of the Irremovable Poor Act of 1861, it is inexpedient, without further information, to legislate on the subject of union rating during the present session."71 The amendment was seconded by Banks Stanhope, whose objections to the Bill were similar to those of the proposer. They were supported by several representatives of the landed interest: Mr Adderley, Sir E. Dering, Mr Newdegate, Sir W. Miles and others. Using arguments that had been heard before, they asserted that the Bill would destroy the parochial system and replace it with something worse; that it would lead to a national rate; and that small rural parishes would pay higher rates and large towns lower ones - thereby creating ill-feeling between town and country. Henley, in a speech of inordinate length, pointed to the disadvantages that would arise as a consequence of

69 Over thirty years later, Sir John Simon, English Sanitary Institutions (London, 1897), p. 301, wrote: "In 1865 the pernicious influence, which we have shown exercised by certain Poor Law conditions, to deprive agricultural labourers of house-room in their place of employment was in great part removed by the passing of the Union Chargeability Act." In a footnote he added: "This Act was promoted by the Poor Law Board under the distinguished presidency of Mr. Charles Villiers. The evidence which the Medical Department had collected the previous year, on the house-accommodation of the rural labouring population, was a material part of Mr. Villiers' case, and was in consequence much attacked by those who opposed the Bill."

70 Sir Edmund's influential article "The Law of Settlement", in: Edinburgh Review, LXXXVII (1848), was reprinted in 1865. It has been republished in Poverty in the Victorian Age, ed. by A. W. Coats (Farnborough, 1973), II: English Poor Laws 1834-1870.

${ }^{71}$ In the course of defending the system of close parishes, he spoke ironically of the "weary and wayworn" labourer having to walk several miles to and from his work, and derided the pity one must feel for such a man as "simply twaddle". The statement was received in the House with "Oh's" of dissent and earned Sir Rainald a rebuke in a leading article in The Times (29 March). In this connection, note a labourer's own words: "He had to get another place, but they would never let Jack gain a settlement; so in bad times Jack was sent to his own parish to find that his cottage was pulled down. He had to live miles away and tear his heart's blood out walking to and from his work night and morning." J. T. Burgess, Life and Experiences of a Warwickshire Labourer, quoted in A. W. Ashby, One Hundred Years of Poor Law Administration in a Warwickshire Village (Oxford, 1912), pp. 79-80. 
the change from a parochial to a union system, and maintained that there would be fewer cottages available, not more.

But though the country members had mustered strongly, some members of the squirearchy spoke in favour of the Bill, and supported it. In a very long and exhaustive debate, a majority of the House favoured the more logical and more just system, whereby the entire burden for providing for the destitute within the limits of the union would bear in equal proportion upon the whole rateable property of the union, and would not, as heretofore, be distributed unequally over separate parishes according to the number of resident paupers in each parish. It was also recognised that the measure would eliminate a large amount of litigation between parish and parish; that it would open a much wider sphere to the labouring poor within which to seek employment without endangering their claim to support in case of necessity; that it would do away with the chief motive for making close parishes; and that it would enable the farmer to select his workpeople on account of their ability to do his work instead of with a view to keeping down his parochial rates. After the county members had unsuccessfully attempted to have the debate postponed, the House divided and the amendment was defeated by 203 to 131 . The Bill had passed its second reading.

Its opponents then gathered in force when it went into committee and, by adverse amendments, sought to obstruct its passage. They managed to extend the debate to over seven hours and it was only adjourned when an interminable filibustering speech of Mr. Knight was brought to an end by a noisy, hostile reaction from the Government benches. At a resumption of the committee stage on 15th May, Henley, as champion of the country gentlemen whose honour had been impugned, made a strenuous attempt to refute the allegations of Dr Hunter regarding the destruction of cottages by landlords. His speech - it occupies no fewer than twenty columns of Hansard - was remarkable only as a feat of physical stamina by a man of 72. Whereas Dr Hunter had used as evidence figures from the census of 1851 and of 1861 , Henley used statistics relating to 1831 and to 1861 , and endeavoured to show that Dr Hunter's findings were false. He did not convince the House, for Villiers, in a forceful and persuasive reply, declared that the pulling down of cottages had been proved by the Commons Select Committee in 1847, by the Poor Law Board Commission in 1851, and by Dr Hunter in 1864, and no doubt it still existed. Henley's speech, he said, was irrelevant to the main object of the Bill. Eminent authorities on the Poor Law had been in favour of its objects. They had included Sir James Graham, Sir George Lewis, Sir George Nicholls and Sir Edmund Head. The farmers were in favour of his measure, too, for it would 
establish a free market for agricultural labour. Now there was a uniform assessment of the union and a uniform contribution to the common fund, little more remained to be done. He asked the House not to support an opposition motion to transfer the Bill to a Select Committee, for that would result in its loss. The House divided, and this motion was rejected by 266 to 93.

At the next consideration of the Bill in committee, Henley made a complete volte-face by proposing the total abolition of removals. ${ }^{72}$ Villiers expressed doubts as to Henley's sincerity, for the latter had in the past always opposed relaxations of the law governing removals, and had done everything he could to prevent the passing of the Bill. He probably thought, said Villiers, that by proposing too much, and creating alarm in the country as to the extent to which the Bill would go, it could be thrown out altogether. He, Villiers, approved of the principle of abolition, but the country was not then prepared for it. Instead, he accepted the motion of $\mathrm{Mr}$ Kekewich, member for Devonshire, to reduce the period of residence for acquiring irremovability from three years to one. Henley's amendment was rejected by 184 to 110 and Kekewich's clause was inserted in the Bill.

Finally, a major amendment was attempted by $\mathrm{Mr}$ Knight, who proposed that sums amounting to almost two million pounds then charged annually upon poor rates should be repaid out of moneys provided by Parliament - that is, from the national Exchequer. The expenses to be repaid would include those for the maintenance of pauper lunatics, establishment charges, and all other expenses connected with the relief of the poor, excepting only for the in-maintenance and out-relief of the poor. Villiers saw the amendment as an attempt to arrest the progress of a Bill which there was no hope of defeating. The object, he believed, was to provide compensation to the owners of close parishes - those persons who would have to pay more rates than hitherto.

The knock-out blow to the amendment was delivered by Mr Gladstone, then Chancellor of the Exchequer. To make this transfer from local to public expenditure, said Gladstone, two million pounds would have to be raised by taxes levied upon items which were consumed in the main by the

72 A similar manoeuvre had been attempted by the country party during the passage of the Irremovable Poor Bill in 1861. "The country is not prepared at present, either for the total abolition of Removals or a great change in the Law of Settlement and the result has always been of proposing too much that nothing at all has been obtained. It is on this account, that you will hear by the opponents of the Bill, that their objection to it, is, that it does not go far enough! and that they desire to abolish Settlement altogether! which should be treated as it deserves, as a mere pretext by interested parties, to oppose a Bill that affects themselves and which they do not like!" Villiers to Duke of Newcastle, 21 July 1861. 
labouring population. He was astounded at the way in which all the opponents of centralisation came forward to centralise when the object was to obtain relief from a pecuniary charge. All the sacredness of selfgovernment appeared to be completely forgotten on an occasion of that kind. With the demolition of Knight's case, the remainder of the committee stage was soon completed.-At the third reading, county members - Henley, Bentinck and Knight - attempted to revive their old arguments, but no debate took place and the measure thus at last passed successfully through the House of Commons.

In the Lords the second reading was moved by Earl Granville, who gave a comprehensive account of the circumstances which had rendered the Bill necessary, and showed that legislation since 1834 had tended to shorten the period of residence which conferred irremovability, and to create a less anomalous rating system. Regarding possible objections, he referred first to the demand for further enquiry, and contended that the matter had been enquired into for years; that each enquiry had been followed by legislation in the direction of the present Bill; and that, after thirty-five years of enquiry, it was time they took some decisive action on a subject of such great importance to the country. Another objection was the necessity, before passing the Bill, of revising the existing boundaries of unions, but Earl Granville urged that it should not be delayed for such a revision, as unions could not be changed without very great inconvenience. Concerning a third objection - that larger areas cost more than smaller ones to administer - he had evidence that the reverse was the case. The Bill, he said, would create a uniform system instead of the existing dual one, which had the disadvantage of relieving part of the poor from one fund and part from another. He called upon the Lords to pass the Bill as a measure important to the labouring classes and therefore vitally important to the whole country.

The principal opposition came from the Duke of Rutland, who moved an amendment that the Bill be referred to a Select Committee. He attacked it on the ground that it would work injustice and unfairness between one class of the community and another, and that it would tend to destroy the parochial system. After a long debate before an unusually full House, the motion of the Duke of Rutland was defeated by 86 to 24 : an unexpectedly large majority of 62 in favour of the Bill. When it went through the committee stage no great change was made, and the Bill passed its third reading on 19th June, receiving the Royal Assent on 29th June (28\&29 Vict., c. 79). The long struggle against prejudice and privilege had at last been won.

One effect of the passing of the Union Chargeability Bill was that it 
opened the way to a progressive reform of the unjust and grossly unequal rating system of the metropolis. Every winter in the poorer metropolitan parishes, homeless destitute persons died in the streets. The reason why these parishes did not make adequate provision for that class of poor was said to be the unequal distribution of the charge. In July 1864, Parliament passed a temporary measure ${ }^{73}$ by which the cost of relief of vagrants was made a common charge on the unions of the metropolis, this charge being an equal one. ${ }^{74}$ Thus no parish should have an inducement to refuse to relieve this class. The following year the measure was made permanent by the Metropolitan Houseless Poor Act (28 Vict., c. 34). The Metropolitan Poor Act of 1867 (30 Vict., c. 6) confirmed the principle of common metropolitan chargeability for the casual poor and extended it to other classes of paupers. Acts of 1869 and of $1870^{75}$ placed the cost of further classes of paupers on the Metropolitan Poor Fund, and created a more uniform system, by which the levy of a common rate was made more equitable. All these measures tended to equalise the metropolitan poor rate and bring the financial basis of the system there more into line with that established over the rest of the country by the Union Chargeability Act. Mr Ayrton would indeed have been pleased that so much of what he had striven for had come to pass.

\section{VI}

In surveying the course of legislation leading to the Union Chargeability Act, the question inevitably arises as to why the reforms so decisively rejected in 1845 became acceptable in 1865 . A possible answer may well lie in the piecemeal, step-by-step nature of the legislation and the emphasis on its moderation. For instance, no attempt was made to change the Law of Settlement, though the period of residence which conferred irremovability was made progressively shorter. The latter change appeared to Parliament much less radical than the former would have been. Yet to those concerned, it was largely a distinction without a difference. Another considerable factor was the change during the period in the balance of forces in the Commons. It has been shown that from 1832 the grip of the landed orders upon Parliament was being steadily weakened. ${ }^{76}$ In 1832 land

73 Poor Relief (Metropolis) Bill (27\&28 Vict., c. 116).

74 Equal in being based on rateable value, a principle introduced by the Irremovable Poor Act of 1861.

${ }_{75}$ Metropolitan Poor Law Amendment Act (32\&33 Vict., c. 63); Valuation Metropolis Act (id., c. 67); Metropolitan Poor Law Amendment Act (33\&34 Vict., c. 18).

76 J. A. Thomas, The House of Commons, 1832-1901 (Cardiff, 1939). 
accounted for $66 \%$ of the interests in the House, and the newer interests commercial, industrial and financial - 34\%. In 1865 the percentages were: land $44 \%$, industry and finance $56 \%$. By this time, the supremacy of the landed interest was said to have disappeared. ${ }^{77}$ During the debates on union chargeability, members claimed that the issue had become one of town versus country, and if this were so in any substantial degree, then the success of the reforming party was inevitable.

Over the years, the evidence produced before the various committees of enquiry and the light thrown on the subject in the course of parliamentary debates had undoubtedly persuaded even members of the country party to vote in favour of reform. The case for the parochial system had worn thin. In 1850, Disraeli had spoken of the "factitious employment" which had taken place, as being "much to the honour" of the employers. ${ }^{78}$ It was a sentiment repeated by the country gentlemen on numerous occasions. During the final debates of 1865 a county member had said that "the landlords did look on the poor as belonging to them individually, and that partly from benevolence, and partly from feelings of the pocket as ratepayers, the landlords and their tenants did employ a vast amount of unprofitable labour."79 Yet though it is undeniable that landlords were often "motivated [. . . ] by the feeling that it was their duty to shield the local labourers from the more extreme consequences of labour surplus by employing as many men as possible",80 a recent study has placed the matter in its true perspective by showing that men whose labour was required at harvest time had to be kept on during the rest of the year. ${ }^{81}$ "By mid-century", states Dr Collins, "occupational mobility of labour had increased, with the underlying tendency for it to move out of agriculture where earnings were limited and confined to just a few weeks of the year, into other industries where wages were higher and employment more continuous. Employers could now no longer rely on the assistance of urban and industrial workers during the summer peaks." 82 The landowners' case, therefore, was based on self-interest rather than on consideration of the welfare of the labourers, who would, on the whole, be better off under the

77 Thomas, op. cit., p. 9.

78 Hansard, CVIII, c. 1026, 19 February. This implied that employers, from the motive of sheer philanthropy, were employing and paying men whose services were not really required.

79 Banks Stanhope, ibid., CLXXVIII, c. 300, 27 March.

80 E. H. Hunt, "Labour Productivity in English Agriculture, 1850-1914", in: Economic History Review, Second Series, XX (1967), pp. 289-90.

81 E. J. T. Collins, "Harvest Technology and Labour Supply in Britain, 1790-1870" (unpublished Ph.D. thesis, University of Nottingham, 1970), p. 20.

82 Ibid., p. 23. 
system which allowed freedom of movement so that they could take their labour to the best market.

There were also prudential motives in the landowners' voting for reform: their reaction to "the real danger to their lives and property when they failed to provide employment for the poor". ${ }^{83}$ The supposed climate of stability in which they lived, their much-vaunted assurance, was to an extent more apparent than real. "From the Revolution to the fall of the Bastille", wrote G. M. Young, "the thought of subversion, of any social crisis more serious than an election riot or a no-popery riot, never entered the minds of Governments. From Waterloo to 1848 it was hardly ever absent." 84 Fresh evidence demonstrates that, during much of the nineteenth century, farm labourers in various parishes throughout the country were engaged in a kind of underground warfare against their employers: committing arson, damaging property, stealing from food crops and poaching. ${ }^{85}$ Members of Parliament were not unmindful of these occurrences, and that violence was not far from the surface, and they said so, too:

It would be most unfortunate [. . . ] if the aggrieved ratepayers were to call to their aid, those poor people who were the victims of the present system, by denouncing to them the great and crying injustice perpetrated on them by the wealthy and powerful. [...] if the body of one of those who died of starvation was held up before the people [...] it would then be very difficult to deal with the subject in a temperate manner. ${ }^{86}$

a more frightful state of affairs he never saw. If the frost had continued a little longer there would have been a fearful amount of agrarian outrages ${ }^{87}$

Statements of this kind could be multiplied. In 1865 they were aware, also, that "the working classes were thundering at their gates", for it was but two years to the passing of the Second Reform Bill.

That a large majority in the Lords had voted in favour of union chargeability is perhaps not so surprising today as it appeared to contemporaries, ${ }^{88}$ for the really large landowners depended even less on agricultural rents than they had done in 1846, at the time of the Corn Law issue. Their

83 Hunt, loc. cit

84 G. M. Young, Victorian England. Portrait of an Age, 2nd ed. (Oxford, 1953), p. 27.

85 J. P. D. Dunbabin, Rural Discontent in Nineteenth-Century Britain (London, 1974), passim.

86 A. S. Ayrton, Hansard, CXLIX, cc. 626-34, 23 March 1858.

87 Alderman Sidney, MP for Stafford, referring to the pressure of recent distress, ibid., CLXI, cc. 240-42, 8 February 1861.

88 Annual Register, 1865, p. 124. 
interests now lay more in rising urban real-estate values and profits on mines and railways. ${ }^{89}$

Villiers had included the Irish poor in the clause granting freedom from removal after one year's residence. Baines had not done this in 1854; but in that year there had been 16,047 Irish removals, 5,043 from Liverpool alone. A widespread fear then prevailed, of being swamped by Irish pauperism. Since that time, the numbers had diminished - in 1864 there had not been a single Irish removal and the matter was no longer an issue.

The Conservative chiefs in both Houses had remained neutral in 1865 , neither Lord Derby nor Disraeli advising the rejection of the Bill. Indeed, after his "Agricultural Distress" motion of 1850 Disraeli never spoke again on this subject; ${ }^{90}$ and though after the second reading of the Union Chargeability Bill he voted loyally with the opposition, the diehard squires were an embarrassment to him and he regarded their leader with contempt. 91

The press, especially The Times, represented a great and growing influence. The average daily circulation of The Times in the mid 1850's was much larger than that of the other five principal morning papers put together ${ }^{92}$ Such was its authority that each set of politicians in turn feared and courted the editor, who went his own way, independent and unmoved, guiding and interpreting the middle opinion of the governing classes in the nation..$^{93}$ The Newspaper Directory wrote in 1864 that The Times "has ever elicited the loftiest, the noblest advocacy: we mean that of the condition and treatment of the poor." It is well-known that The Times had been hostile to the New Poor Law from the start; and this accounts for its opposition to Graham's Bill in 1845, when the latter first proposed a transfer of power from the parish to the union. By 1865 , however, the evils of the existing system had become notorious, and The Times placed all the weight of its great influence behind the Union Chargeability Bill, making a national issue of it, and following its parliamentary progress with powerful and eloquent leading articles in its favour. ${ }^{94}$ The Bill was supported by

89 E. J. Hobsbawm, Industry and Empire (London, 1968), pp. 85-86.

90 By 1852 he had renounced the principle of protection. Disraeli's Reminiscences (London, 1975), p. 48.

91 Note Disraeli's description of him: "Henley [. . . ] sat [ . . ] with the countenance of an ill-conditioned Poor Law Guardian censured for some act of harshness. His black eyebrows which met, deeply knit; his crabbed countenance doubly morose; but no thought in the face, only ill temper". Blake, Disraeli, op. cit., p. 304.

92 Asa Briggs, The Age of Improvement (London, 1959), p. 428.

${ }_{93}$ Sir Edward Cook, Delane of The Times (London, 1916), p. 34.

94 The dates of these articles are as follows: 25 February, 28 and 29 March, 1 April, 12 , $16,20,24$ and 26 May, 13 June. 
other national dailies, only The Morning Herald, the organ of the country party, continuing "to defend the indefensible". The influence of the press and its considerable public appeal undoubtedly gained a response in Parliament.

The Bill, said the Annual Register, was regarded by the public as one of the most beneficial and valuable fruits of the session of 1865 . Did it result in an improvement in the rural housing situation? It is difficult to be specific, for authorities differ; and the housing shortage has continued into our own day. W. Hasbach, basing his conclusion on the results of the 1885 Royal Commission on the Housing of the Working classes, maintains that the 1865 Act seems to have had hardly any effect on housing for the agricultural labourer beyond hindering the pulling down of cottages. There was nothing to show that new housing had been built to any great extent. ${ }^{95}$ On the other hand, Clapham asserts that the Act removed the main incentive to keeping down the parish stock of cottages, and combined with good prices and rents to make the quarter of a century from 1854 to 1879 one of very active building of "estate" cottages. ${ }^{96}$ A recent study by $\mathrm{Dr}$ Pamela Horn tends to confirm Clapham's findings. It shows that as a result of the passage of the Union Chargeability Act the number of new "estate" cottages built in the 1860's did increase. Nevertheless, throughout the nineteenth century their number remained limited. ${ }^{97}$

One thing is beyond doubt: whether they built cottages or not, the landlords were no longer able to evade paying their share of poor rates, while the agricultural labourer enjoyed increased freedom of movement and was less subject to the iniquities of removal. The Act can certainly be seen as a milestone on the road to social justice.

95 W. Hasbach, A History of the English Agricultural Labourer (London, 1920), p. 303.

${ }^{96}$ Sir John Clapham, An Economic History of Modern Britain, II (Cambridge, 1926), p. 509.

97 Pamela Horn, Labouring Life in the Victorian Countryside (Dublin, 1976), p. 14. 